\title{
Invisibilidades cruzadas
}

\section{Uma aproximação ao conceito de o momento decisivo de Henri Cartier-Bresson ${ }^{1}$}

Paulo Menezes

Para Ana Lúcia

Uma fotografia antiga de Cartier-Bresson nunca me sai da cabeça. É uma foto especial, que desdobra uma série incomensurável de olhares, associados a pelo menos um engano básico.

Trata-se de uma foto muito conhecida ${ }^{2}$, tirada em 1932 atrás da Gare Saint-Lazare, em Paris. Mostra um terreno circundado por uma grade e um muro, totalmente tomado por uma imensa poça d'água que reflete em sua superfície um pedaço daquele muro além de um transeunte que passa por ali. No centro, físico e imaginário, a foto mostra uma pessoa que acabou de pular (imaginamos) por cima dos degraus de uma escada de madeira, caída sobre a água, de onde pegou impulso para um salto final, na tentativa de chegar mais perto de algum lugar seco, onde pudesse caminhar adequadamente sem molhar os pés. A fotografia, que paralisou a pessoa no ar, no meio do salto, deixa claro o insucesso dessa tentativa, pois seu pé esquerdo já está quase tocando a superfície da água que ele parecia ter desejado evitar até então. Não vemos, mas podemos imaginar, e pressupor, que esse salto terminou dentro da água. Mas é interessante ressaltar que esta imagem, do homem em pleno voo, redobra, e atualiza, outra imagem que pode passar despercebida, estampada em um cartaz que está colado no muro, no fundo da cena, provavelmente de uma propaganda de circo, na qual vemos uma bailarina executar um passo de dança muito semelhante àquele

1. Agradeço ao CNPq o apoio para a realização desta pesquisa.

2. Até o verbete sobre Cartier-Bresson na Wikipédia traz essa foto como "exemplar" de o momento decisivo. 


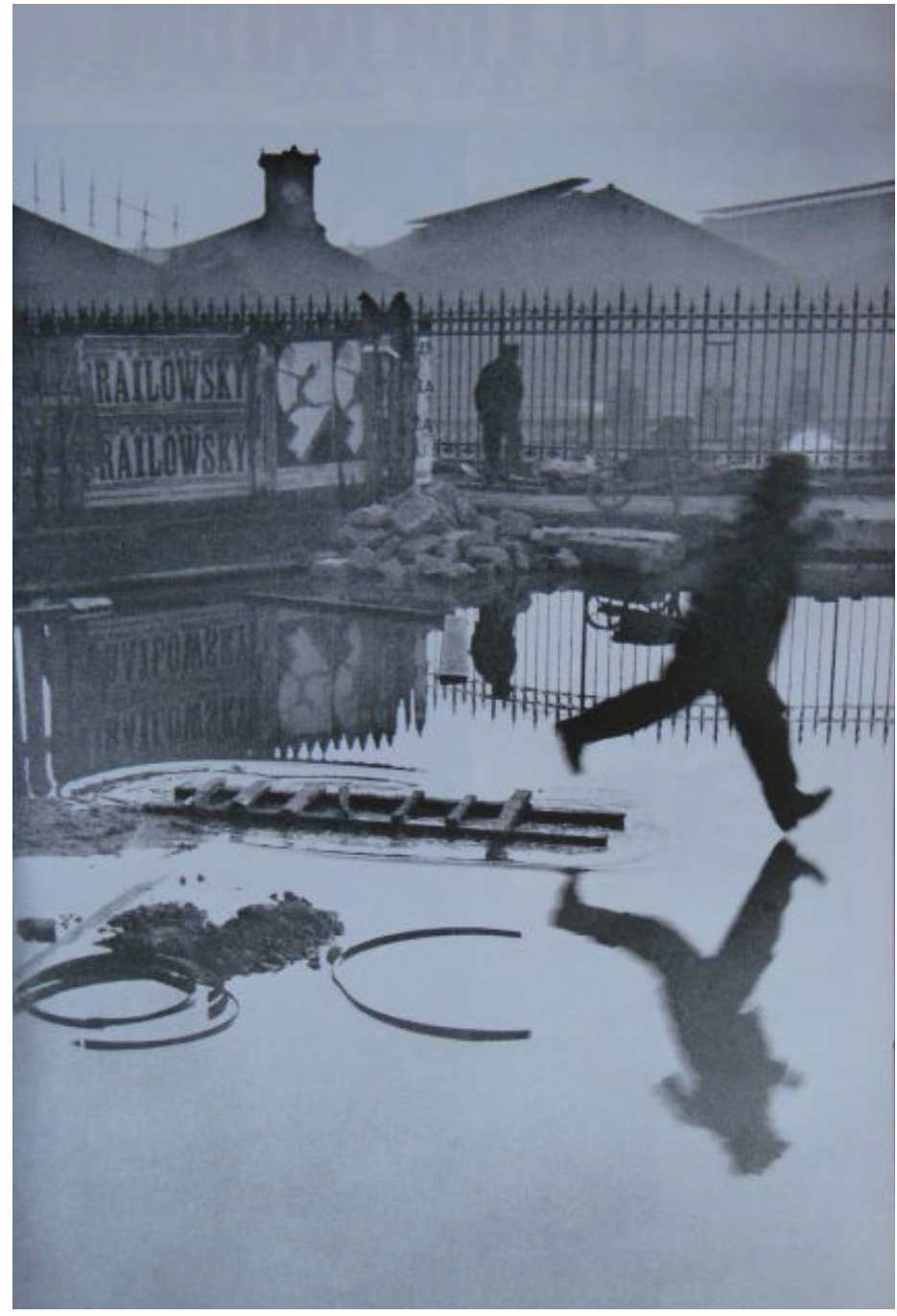

Henri Cartier-Bresson, Sem título, Paris, 1932.

que executa o infortunado transeunte. A imagem está borrada pelo seu próprio movimento e se duplica de maneira acentuada pelo reflexo exato que se pode ver sobre a superfície da água, superfície que também duplicou de maneira espelhar o salto da bailarina de circo, no cartaz.

Eu não saberia dizer quantas vezes vi essa foto em publicações, exposições, ombreada por muitas outras imagens. Ela sempre se destaca do conjunto, sempre resta isolada pela memória, sempre heterônoma ao conjunto que em vão tenta inscrevê-la em uma dimensão mais ampla. Parece querer, e conseguir, portar-se a si mesma independentemente do que esteja ao seu lado, afirmar sua autonomia enquanto imagem de quaisquer outras possibilidades discursivas nas quais poderia ser integrada. 
O problema, que remete ao engano, é associar essa imagem e seu momento especular, e absolutamente transitório, à naturalização irreflexiva do famoso conceito cunhado por Cartier-Bresson e disseminado pelo mundo como explicativo de seus pontos de partida e de chegada: o conceito de o momento decisivo, expresso pela primeira vez em seu livro Images à la sauvette, de 1952, e imortalizado na versão em inglês do mesmo ano com o título The Decisive Moment.

Não que essa fotografia não possa bem expressar o que Cartier-Bresson entendia por momento decisivo, mas, e é essa a nossa questão, ela pode aludir no espectador sentidos muito diferentes e distantes daqueles que se constituem com base na interpretação das ideias e de outras fotos de Bresson.

Em uma primeira aproximação, essa fotografia pode suscitar no observador que o momento decisivo é um momento fortuito, fruto do acaso e da sorte de estar no lugar certo e na hora certa, como acontece quando se consegue fotografar a explosão de uma espaçonave ou a queda de um cometa. Nada mais longe do pensamento de Bresson do que aproximar suas fotos desse acaso "criativo", por mais espetacular que ele possa ser enquanto resultado. Pelo contrário, se levarmos em conta o conjunto das 125 fotos publicadas no livro, ou mesmo das várias outras realizadas ao longo de sua carreira, pode-se ver que esta foto é extremamente heterodoxa em relação à sua produção visual. São poucas as fotos de Bresson em que encontramos uma imagem tão repleta de contingências e suspensões, tão aparentemente tomada pelo acaso como esta. Daí talvez a alusão ao engano de se tomar, e pensar, o momento decisivo como fruto do transitório, como fruto da sorte ou de um acaso feliz, por mais infeliz que possa ser seu assunto ou tema ${ }^{3}$.É evidente que o momento suspenso do salto daquele transeunte permite essa leitura imediatista do que se poderia conceber como momento decisivo, pois, como nunca, essa foto expressa a fixação de um momento único, sem antes nem depois, uma fração essencial de tempo e espaço captada pelos olhos atentos do fotógrafo e pelas mãos rápidas que disparam o obturador. Nessa direção, pode parecer a quem a olha que ela é apenas fruto de um lampejo de sorte que permitiu ao fotógrafo captar esse momento especial no fluxo dos acontecimentos que permeiam o dia a dia e que, sem esse recorte feliz, estaria perdido no caos dos fenômenos cotidianos aos quais não se dá nenhum significado.

Mas a interpretação desta fotografia pode seguir outras direções. Pode-se perceber que o desdobramento do salto da pessoa com o salto de sua própria imagem

3. Ver, por exemplo, o catálogo da exposição sobre Cartier-Bresson no Sesc Pinheiros (2009), em que o curador afirma: "Para Cartier-Bresson, importa prioritariamente o momento breve em que, ao acaso, forma e conteúdo espreitam a composição perfeita”, ou o título da dissertação Henri Cartier-Bresson: o acaso objetivo - propostas gráficas para uma análise comparada da fotografia no século $X X$, de José Alves Linhares Filho, Universidade Federal do Rio de Janeiro (UFRJ), 2004. 
refletida na água não é circunstancial; ao contrário, permite ao observador duplicar, por um ângulo invertido, a imagem que os olhos mal poderiam ver se estivéssemos observando a cena in loco. Da mesma forma que a bailarina, em seu salto perfeito, desdobra a um só tempo o salto daquele homem, enquanto seu reflexo na água desdobra o reflexo na água do salto do mesmo homem. Duplo desdobramento, remete a duas dimensões da imagem, que são assemelhadas e ao mesmo tempo distintas: os saltos e seus reflexos invertidos na água, invisíveis a olho nu.

Essa talvez seja uma daquelas fotografias que Bresson dizia ter a capacidade de contar uma história por si mesma, o que ele afirmava ser raro: “Às vezes, existe uma única fotografia cuja composição possui tanto vigor e riqueza, cujo conteúdo se irradia por si mesmo para fora, que essa foto em si é toda uma história. Mas isso raramente acontece" (1952, p. 12). Aqui, Cartier-Bresson aponta para duas questões. A primeira, que as fotografias não deveriam ser fruto do acaso, feliz ou não, mas de um incessante trabalho do olho e da mente do fotógrafo no sentido de encontrar, quase instantaneamente, uma composição rigorosamente ideal para se expressar um momento retirado do fluxo dos fenômenos da vida cotidiana e aí dotado de sentido por intermédio das câmaras. A segunda, de que tomar uma única foto ou, ao contrário, um conjunto articulado de fotos pode aludir à proposição de sentidos muito diferentes nos discursos articulados e propostos pelo observador. Se uma fotografia tomada individualmente pode passar a ilusão de que ela fala apenas sobre o mundo externo, um conjunto de fotos, o que Bresson chamava de reportagem fotográfica, ou de história fotográfica, pode indicar que se esteja falando, sobretudo, sobre outra coisa, sobre valores e conceitos que orientam aquele discurso fotográfico sobre o mundo, mais do que sobre o próprio "mundo. "A história fotográfica envolve uma operação conjunta do cérebro, do olho e do coração. O objetivo dessa operação conjunta é retratar o conteúdo de algum evento que está no processo de desdobramento e aí comunicar impressões" (Idem, ibidem). Isso deixa claro que para Bresson o conceito de o momento decisivo está muito longe da ideia de se tirar fotos ao acaso, pois é fruto de um longo processo de elaboração para dar forma e, portanto, composição e valor aos acontecimentos retirados do mundo e de seu fluxo incessante de fenômenos, aludindo com isso sentidos diferenciais para as possíveis interpretações de diferentes observadores ${ }^{4}$.

Ao olharmos para outras de suas fotos, como os ensaios fotográficos das prostitutas da Espanha e do México, novas possibilidades interpretativas se abrem. Em

4. Só como curiosidade, seus famosos retratos eram realizados por meio de um artifício curioso. Bresson batia o equivalente a dois filmes de fotografia sem nada dentro da câmera, no sentido de naturalizá-la para o fotografado. Depois disso utilizava mais seis filmes e, dentre essa grande quantidade de fotos, escolhia aquela que no seu modo de ver era a expressão mais elaborada da pessoa fotografada. 
Demoiselles dans une maison close d'Alicante (Espanha, 1933), Alicante (Espanha, 1933) e Calle Cuaubtemoctizin (México, 1934) não há sinal de imediatismo, nem nada que possa remeter a qualquer acaso ou instantâneo. Pelo contrário, as três fotos transmitem uma cumplicidade e uma intimidade que obviamente a foto da Gare Saint-Lazare não poderia revelar. Aqui, as mulheres olham diretamente para a câmera, sem meio termo, sem hesitação. Na primeira, três mulheres: duas estão deitadas, uma de costas para o fotógrafo, e para o observador, usa ligas e sutiã e mostra em primeiro plano suas nádegas bem desenhadas que ressaltam seu corpo nu; a outra, de calcinha e sapato, olha diretamente para a câmera; a terceira, ao fundo, parece fazer ginástica encostada em uma parede, com um braço apoiado sobre o chão e o outro sobre a cintura, enquanto sua perna esquerda se exercita marcando a imagem com seu movimento. Na segunda foto, as mesmas duas mulheres que antes olhavam para a câmera agora estão sentadas, de frente para nós, de pernas abertas, uma em posição frontal com os grandes seios à mostra e a outra em posição lateral.

A foto do ensaio realizado no México mostra duas mulheres através de duas portinholas que fazem as vezes de janelas em um grande portão carcomido de madeira na rua. Uma, de olhos fechados, está com meio corpo para fora; a outra, sentada, apoia seu braço esquerdo sobre a aberturada portinhola e olha fixamente para a câmera.

Marcante nessas fotografias é o olhar altivo dessas mulheres, nada inferiorizado ou submisso como a convenção da pintura costuma retratá-las ${ }^{5}$, sempre em poses lânguidas dando seu corpo a saborear para os olhos do espectador, nunca o olhando diretamente nos olhos, nunca questionado seu lugar primordial de voyeur e de senhor. Aqui, em contrapartida, a impressão é de que vemos várias Olympias de Manet ${ }^{6}$, que olham diretamente nos olhos do observador, sem vergonha de seus trajes rotos, sem desonra pela sua situação social, sem se colocar em uma posição que reforce a prevalência e a superioridade dos olhares externos e morais sobre elas.

Deve-se ressaltar que a intervenção do fotógrafo não é só necessária, mas essencial, pois é ele que recorta, seleciona, organiza e dá sentido visual ao mundo, segundo seus valores. "É essencial recortar do material bruto da vida - recortar e recortar, mas recortar com discriminação. Quando ele está trabalhando, o fotógrafo deve alcançar uma precisa consciência do que está tentando fazer" (Idem, p. 12). Certamente uma foto mostra muito mais do que sua pretensa autonomia e objetividade poderia deixar perceber. "Eu acredito que, no ato de viver, a descoberta de nós mesmos é feita concomitantemente com a descoberta do mundo que nos cerca, que pode modelar-nos, mas

5. Ver o belo ensaio a respeito das representações das mulheres nas pinturas realizado por John Berger (1980, pp. 49-68).

6. Uma análise mais circunstanciada dessa pintura pode ser encontrada em Menezes (1997, pp. 51-52). 
Invisibilidades cruzadas, pp. 211-233

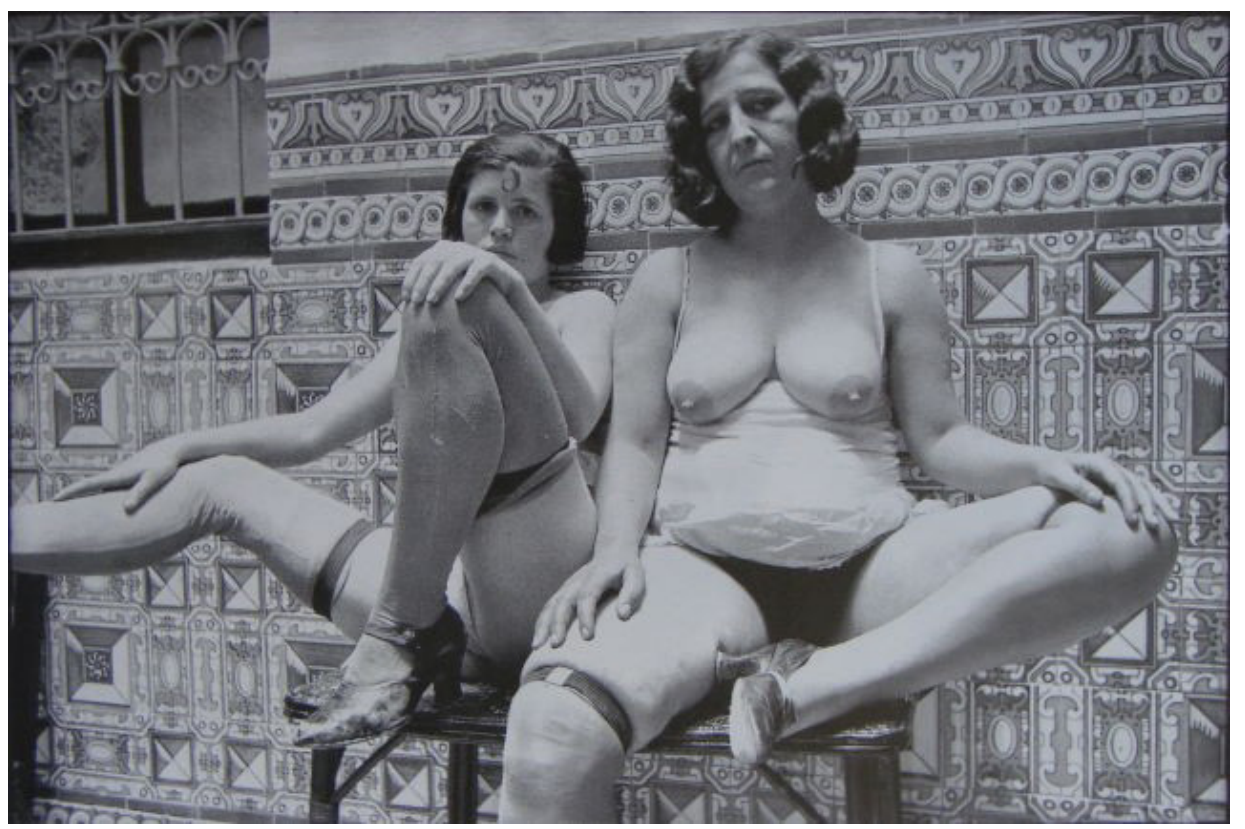

Henri Cartier-Bresson, Alicante, Espanha, 1933.

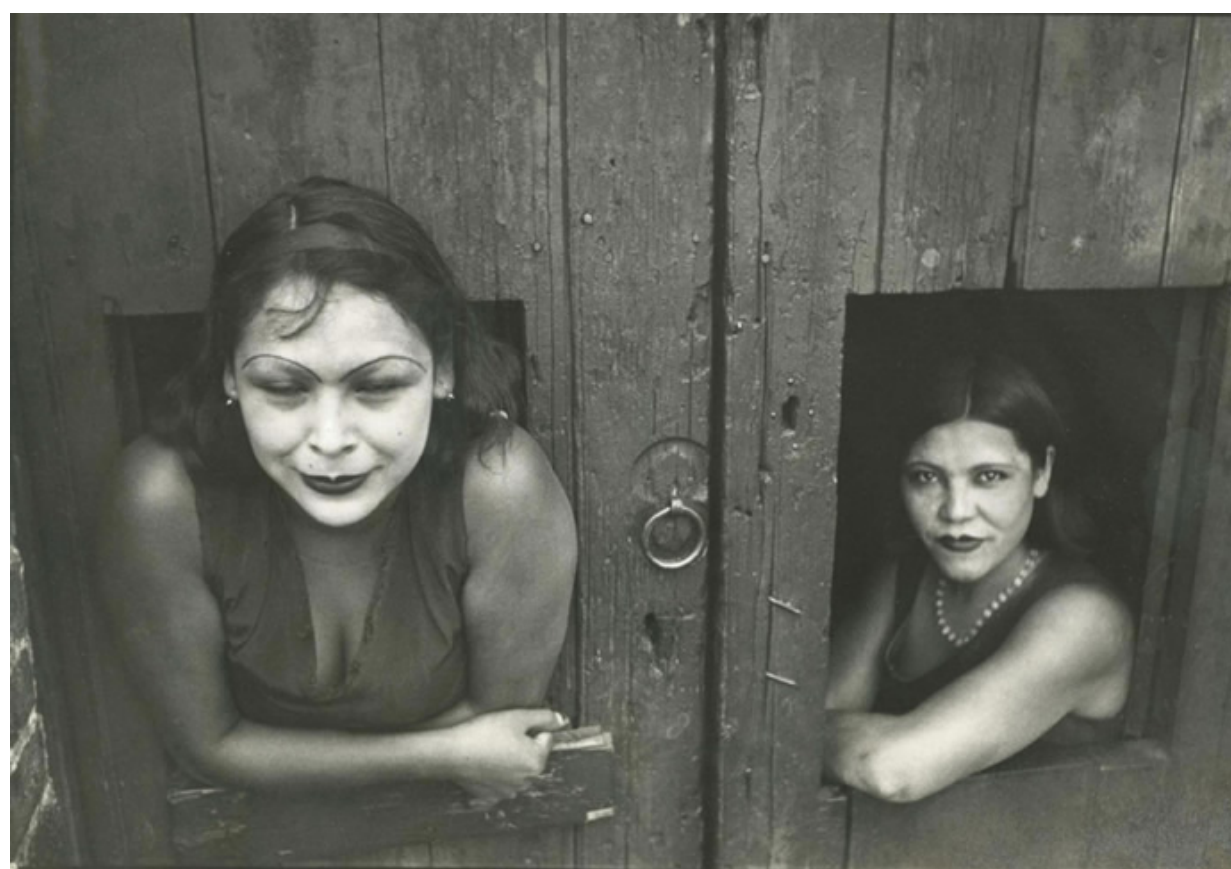

Henri Cartier-Bresson, Calle Cuauhtemoctizin, México, 1934. 


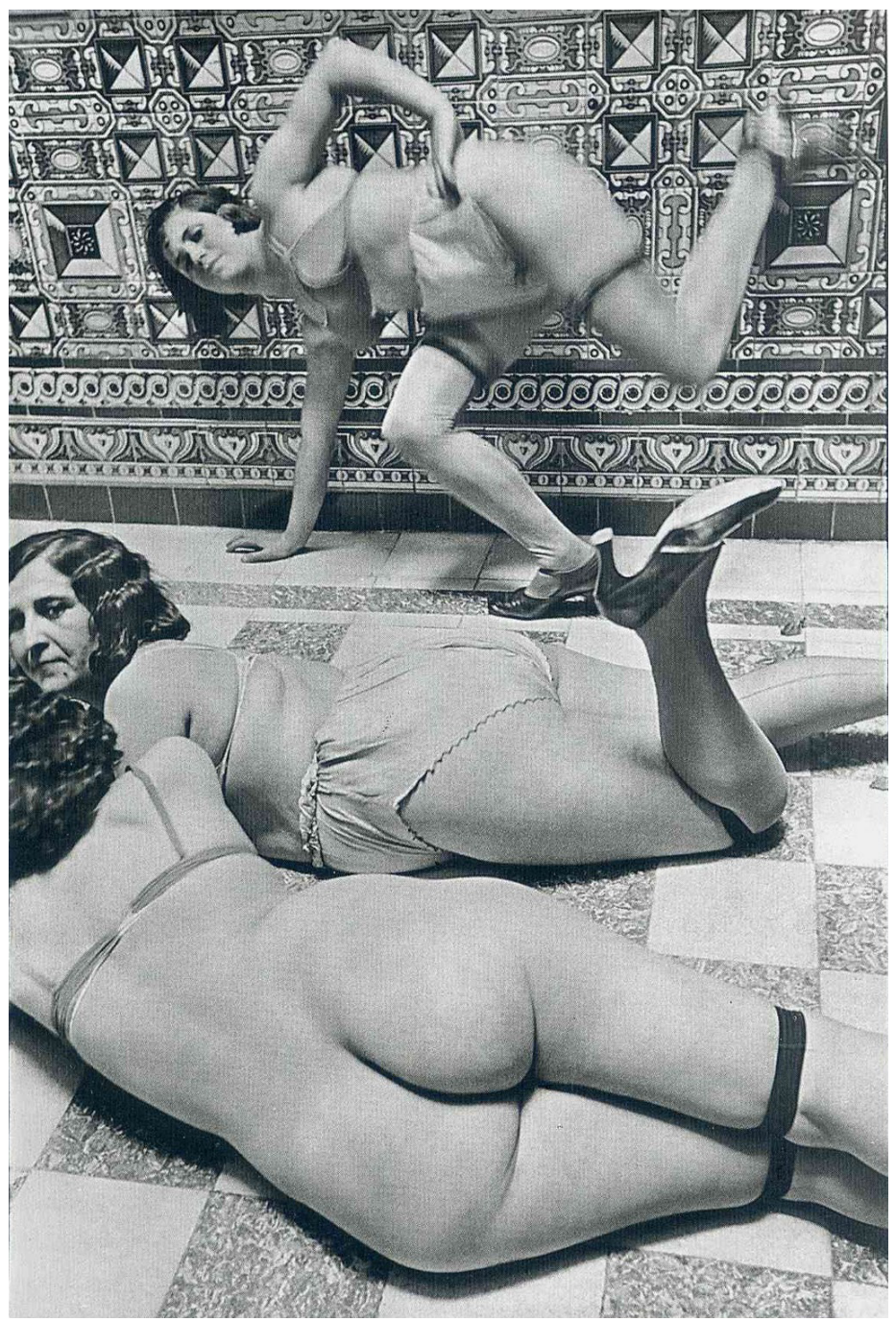

Henri Cartier-Bresson, Demoiselles dans une maison close d'Alicante, Espanha, 1933. 
que também pode ser afetado por nós" (Idem, p. 17). Assim, embora Bresson ressalte o caráter absolutamente construtivo da imagem fotográfica, que recorta e interpreta o mundo de acordo com os valores que orientam o recorte, ele mostra que, se isso é difícil em uma fotografia isolada, em um ensaio fotográfico o campo está aberto para que o observador olhe não apenas o recorte que lhe foi oferecido, mas investigue também os valores e os critérios que orientaram e definiram tal seleção - valores do fotógrafo e não do mundo. "Por forma eu entendo uma rigorosa organização da inter-relação de superfícies, linhas e valores. É somente nessa organização que nossas concepções e valores se tornam concretos e comunicáveis" (Idem, p. 17). Nesse sentido, as fotos de Bresson ressaltam, evidentemente, não o lugar comum dos olhares sobre a prostituição, nem as composições de pintura que fizeram a história das representações desse gênero, que vão ter em Olympia sua perspectiva negativa e questionadora. Uma imagem não fala diretamente do "real", mas constrói uma realidade de imagem que dialoga decidida e acentuadamente com outras imagens realizadas sobre assuntos correlatos no universo das imagens. Ele retoma, dessa maneira, o que disse Francastel a respeito da imagem: "existe em si, ela existe essencialmente no espírito, ela é um ponto de referência na cultura e não um ponto de referência na realidade” (1983, p. 193). Uma imagem, nessa acepção, dialoga antes com outras imagens e não diretamente com o "real", do qual, aparentemente, parece nascer. É nessa encruzilhada de trocas e invisibilidades que se constituem as possibilidades de interpretação significativa do mundo por meio das configurações propostas pelas imagens e de sua reinterpretação pelos sempre inúmeros observadores.

Olhar aquela primeira foto nos faz ainda pensar em outras direções, em um mundo que não é visível a olho nu. Primeiro, pelo momento absolutamente transitório ali revelado e que os olhos, pela velocidade com que tudo aconteceu, não poderia de maneira alguma captar. Os olhos não têm a capacidade de selecionar parte dos movimentos que captam, mas apenas a sua continuidade. Assim, aquele momento que a fotografia de Bresson mostra, de uma pessoa em pleno pulo, milésimos de segundo antes de cair com o pé na água, é uma realidade apenas da imagem, construída e materializada por ela, que só poderia ser vista enquanto imagem, e não na inesgotável continuidade dos fenômenos do mundo. Ao retirar esse fragmento do incessante aparecer e desaparecer dos fenômenos do mundo cotidiano, essa imagem faz com que o observador olhe através dela um mundo não visível, justamente porque faz parte da multiplicidade de ocorrências do dia a dia, que sempre se apresentam em sua continuidade espaço-temporal. Isolar, portanto, algum fenômeno dessa dupla continuidade é construí-lo para a apreciação, rompendo definitivamente com o mundo tal qual ele se apresenta aos olhos, para mostrá-lo em uma nova configuração, que só é possível por meio da imagem e de suas características próprias. A 
seleção (e exclusão) que ela promulga muito se destaca da realidade da qual surgiu, por mais que sempre acabe aludindo a ela como vestígio ou, como queria Benjamin (1986, p. 94), sendo chamuscada por ela. Mas o que ela tem de mais interessante é justamente esse afastamento que permite aos olhos verem coisas que normalmente eles não têm a capacidade de ver, ou porque simplesmente não enxergam, ou porque não recortam o que veem dessa maneira. Assim, não se deve pensar as imagens fotográficas como uma "paralisação do tempo", nos termos de Bazin - "a fotografia não cria, como a arte, eternidade, ela embalsama o tempo, simplesmente o subtrai à sua própria corrupção" (1983, p. 126). Isso porque o tempo que ela aparentemente embalsama não é um tempo abstrato e destituído de valores, mas um tempo-espaço retirado de sua continuidade pela seleção de quem olha por meio das lentes e aperta o obturador no momento preciso, mantendo uma temporalidade própria. Nessa direção podemos entender o que Cartier-Bresson quis dizer ao afirmar que a "fotografia é o reconhecimento simultâneo, em uma fração de segundo, do significado de um evento bem como da precisa organização de formas que deu a esse evento sua própria expressão" (1952, p. 17).

Além disso, essa mediação mecânica - que se incrusta até mesmo na psicologia da imagem, o que é reforçado pelo próprio nome dado às lentes fotográficas, as objetivas - provoca o engano final de tomar como objetiva a imagem perante seus olhos por ser fruto de um processo no qual o homem está (no imaginário) elidido, e que se mostra como a mera transposição direta de uma realidade exterior para a realidade da imagem (Bazin, 1983, pp. 124-126). Poderoso atributo psicológico, que dá às imagens fotográficas e cinematográficas um "coeficiente de realidade", uma "capacidade de ilusão" que nem mesmo a melhor das pinturas jamais conseguiu ter.

Ademais, a foto na Gare Saint-Lazare aponta ainda para uma outra direção, ainda mais sugestiva. Veja-se, por exemplo, a pintura Casal Arnolfini (1434), de Jan Van Eyck (1390?-1441). A cena é prosaica. Mostra um casal que está de pé, de mãos dadas, em seu quarto de dormir. Ele, com a mão direita levantada à altura do peito, veste-se com uma longa capa marrom, circundada por uma fina pele da mesma cor, e porta um grande chapéu preto, que parece ser enorme em virtude dos traços finos e longilíneos que detalham sua cabeça, ligeiramente voltada, como seu olhar, para a direita e para baixo. Ela, grávida, com a mão esquerda sobre a barriga, símbolo de proteção, veste, sobre um vestido azul, um longo sobrevestido verde, complementado por um mantô do mesmo tecido com mangas alargadas e circundadas por uma pele clara de onde sai uma espécie de debrum ornamentado que volteia o mantô de lado a lado. Por sobre a cabeça, delicadamente disposta, uma renda trabalhada lhe cai até tocar suavemente os ombros. Seu olhar, como o do marido, volta-se para baixo. Ela se encontra mais perto do enorme leito, que toma 
todo o lado direito da pintura, inteiramente decorado em tecido vermelho, desde o vistoso dossel e as cortinas até os lençóis e a colcha alinhadamente esticados sobre a cama. Mais ao fundo, nota-se uma cadeira de madeira escura, assim como a lateral de um móvel talhado com esmero trabalho artesanal. Sobre suas cabeças pende um enorme candelabro de velas, em bronze cinzelado, todo esculpido em cada um de seus braços. Na parte inferior, há dois pares de chinelos de madeira que, por suas dimensões, pertencem a cada um dos membros do casal. Aos seus pés, entre eles, vemos um pequeno cachorro, estático como todos na tela, mas que, diferentemente do casal, olha para o pintor, e para o observador, diretamente nos olhos. Tudo nessa cena remete a um casal de posses, mas não nobre, realçando as camadas sociais em ascensão no então novo mundo do capitalismo comercial.

Entre o homem e a mulher, no centro latitudinal da imagem, na altura de dois terços, encontra-se, quase que por acaso, como um momento insignificante de decoração, um espelho de dimensões medianas, com moldura entalhada em madeira, em completa harmonia com os objetos do quarto, e que é, como toda a cena, iluminado pela luz que entra por uma janela caprichosamente instalada no lado esquerdo do cômodo.

Contudo esse espelho, diferentemente do que se poderia imaginar, não é apenas um simples espelho: contra todas as expectativas, não é plano, mas convexo. Artifício que ressalta as artimanhas do pintor, o espelho funciona como uma grande angular das câmeras fotográficas, ampliando o campo de visão da imagem que lá se forma de maneira a abranger muito mais do que o ângulo normal de visão humana. Mas esse estratagema vai muito além do mero exercício quantitativo da representação visual. $\mathrm{O}$ espelho não reflete o que convencionalmente se espera de uma imagem especular - um reflexo do mundo e das coisas, um redobramento do mundo visível na imagem representada. Aqui, pelo contrário, o que se mostra é um desdobramento da imagem inicialmente representada na pintura. Em vez de expor um reflexo inerte do que já está lá, abre a imagem suavemente para a representação - mesmo que pequena e distorcida - do que se poderia prever na primeira imagem, mas que, justamente pelo posicionamento físico de seus personagens, se furtaria ao olhar daqueles que a observam. Assim, ao contrário de redobrar a imagem já vista, esse espelho especial desdobra o que os olhos não teriam a capacidade de ver, aquilo que resta escondido, tendo em vista o posicionamento das coisas na imagem. Revela-se, portanto, tudo o que antes não se via, tudo que se escondia na imagem pelo olhar que recobra o ponto de vista do pintor em um cubo cenográfico relativamente encurtado em relação às leis da perspectiva tradicional.

Pode-se enxergar, por meio do que esse espelho "reflete", a mesma cena de antes, mas de um ponto de vista radicalmente oposto, a exatos $180^{\circ}$ de onde se encontrava o pintor e, agora, encontram-se todos os sucessivos observadores. Nessa imagem 


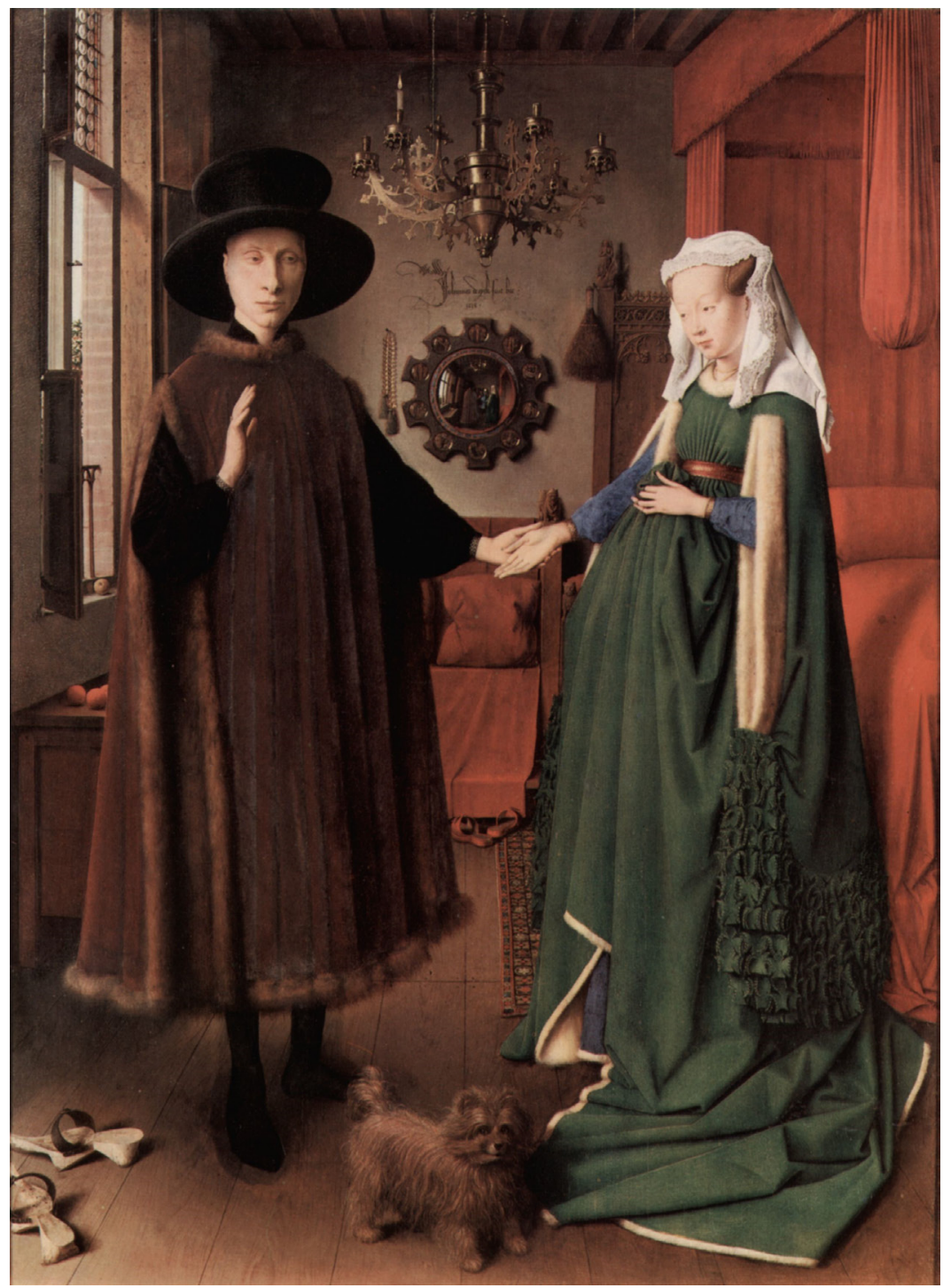

Jan Van Eyck, Casal Arnolfini, Bruges, 1434.

dentro da imagem, aparecem em maior dimensão tanto a janela que o ilumina como o panejamento vermelho da cama que está do lado oposto a ela, com o candelabro a se esgueirar entre eles. Mais ao fundo, pode-se visualizar novamente o casal Arnolfini, agora de costas, desdobrando em sua diminuta imagem a terceira dimensão que uma representação plana não teria como realizar, mas apenas aludir por meio de uma laboriosa constituição do volume em claro-escuro, que recobra para os olhos a percepção de distância e profundidade. Além disso, o espelho sutilmente vai mostrar o que não se podia ver, desenhando para nossos olhos o casal Arnolfini de costas - o marido do torso aos pés e, da esposa, passamos a vislumbrar um pedaço alvo de sua face direita, 


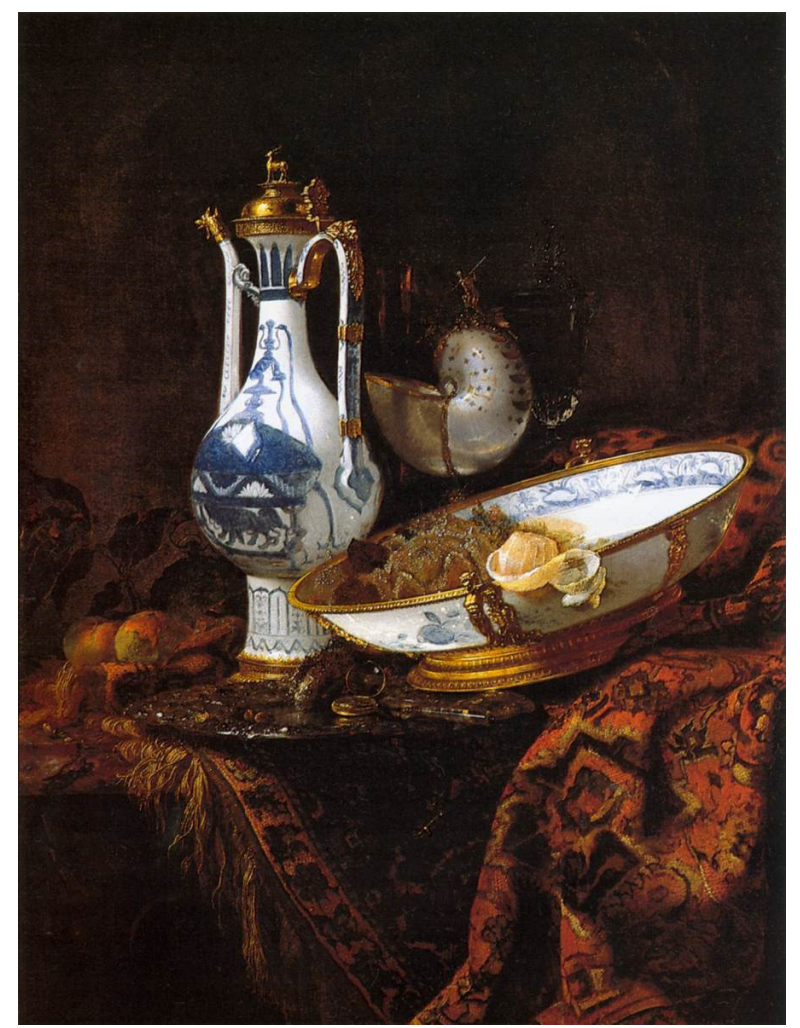

Willem Kalf, Natureza-morta com aquamanile, fruta e um cálice de nautilus, Roterdã, 1660.

antes escondida pelo posicionamento torneado de sua cabeça. Mas isso não é tudo. Em seu novo papel de desdobramento, essa nova imagem acaba por mostrar também o que antes não estava na imagem original. Ao lado dos elementos compositivos do ambiente - o casal, os móveis, a janela, a luz - aparece, bem no meio da cena, bem no meio do espelho, uma nova figura, de frente para nós, vestida em um tom de azul suave e claro, o que lhe permite se destacar dos tons escuros e marrons que tomam a pintura quase que por completo. Invisível no primeiro plano, mas visível no último, esta figura representa não apenas a cena, mas o conceito especular diferencial que se tornaria tradição na pintura flamenga, e depois holandesa, em especial no século XVII, e que teve desdobramentos posteriores. Nesse sentido, esse "espelho" é muito mais que um espelho a refletir o sempre visto. Ele é também o desdobramento do que os olhos não podem ver do ponto de vista em que se encontram, ao mesmo tempo que engendra um conceito de imagem como possibilidade única de se ver justamente aquilo que é continuamente furtado à vista e ao olhar, de ver na imagem justamente aquilo que os olhos não têm a capacidade de ver quando olham. 


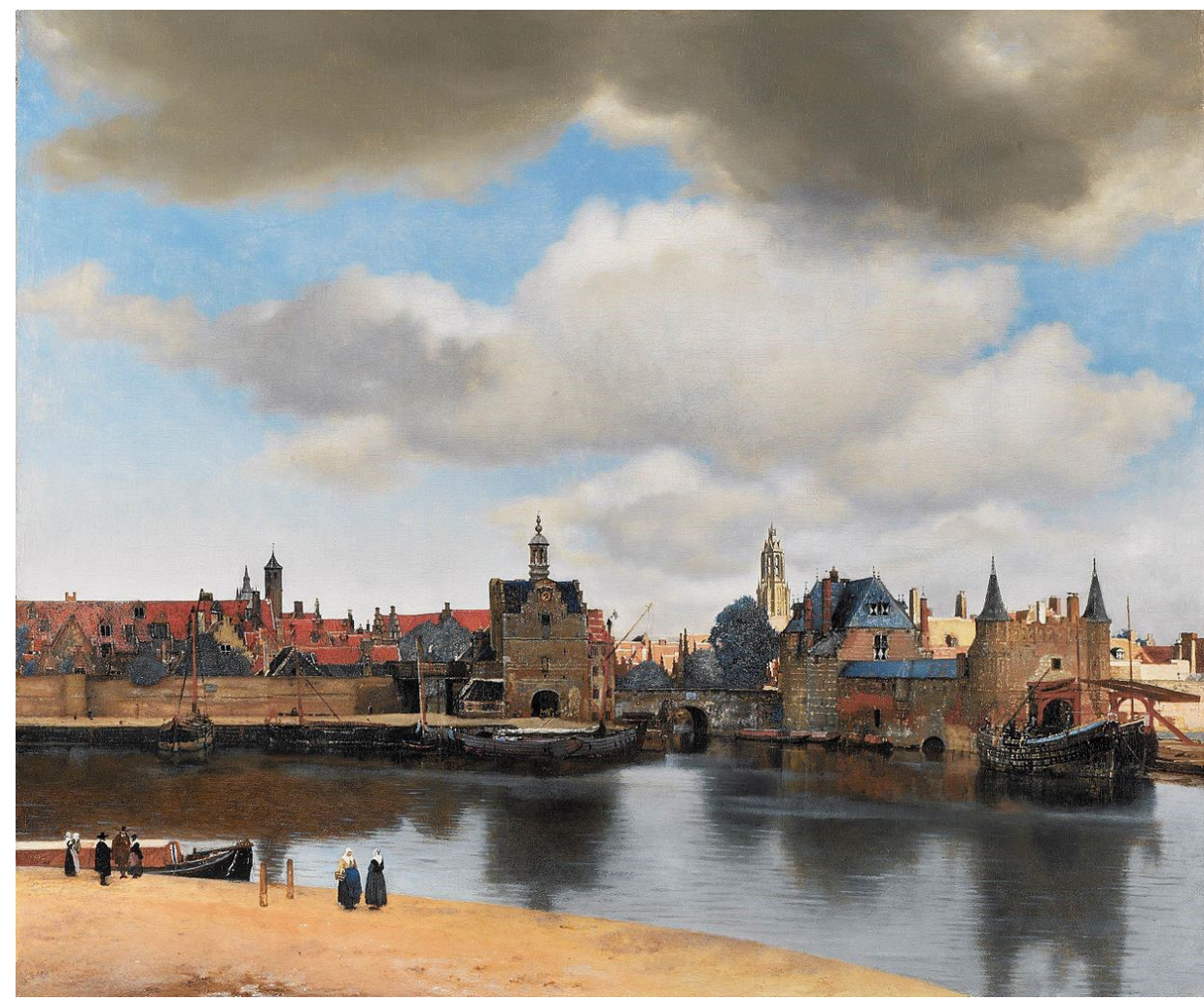

Johannes Vermeer, Vista de Delft, Delft, c.1660-1661.

Tradição que encontrou no passar dos anos as mais variadas formulações ${ }^{7}$, de Diego Velázquez (1599-1660) ${ }^{8}$ a Johannes Vermeer (1632-1675), ou de Willem Kalf (1619-1693) a Pieter Claesz ${ }^{10}$ (1597-1660). Vermeer havia utilizado esse artifício em seu quadro Lição de Música (1662-1664), onde um espelho plano cuidadosamente colocado e inclinado sobre um piano mostra o rosto da moça que toca o instrumento, o que antes não poderíamos ver por ela estar de costas para o pintor/observador; ou no reflexo do vidro de uma janela, como se vê em Moça lendo uma carta com a janela aberta (c. 1657-1659), onde por seu posicionamento lateral podemos ver de frente o rosto da moça que antes só podíamos ver de perfil pela imagem principal. Mas o momento mais espetacular dessa técnica encontra-se

7. Gombrich (1985, pp. 325-340) chama essa tradição de "reflexo da natureza".

8. Ver, por exemplo, a tela Las meninas (1565). Para uma discussão heterodoxa dessa tradição, ver Foucault (1981, pp. 19-31).

9. Ver, entre outras, Still life with Chinese sugar jar, glass goblet and fruit (1672), onde a janela e a lateral do quarto aparecem no reflexo do copo de cristal e da jarra de suco.

10. Ver, por exemplo, Still life with stoneware jug, wine glass, herring, and bread (1642), onde a janela $\mathrm{e}$ uma figura humana estão no "reflexo" do cristal do copo de vinho. 
em duas de suas mais conhecidas pinturas: Vista de Delft (c.1660-1661) e Moça com brinco de pérolas (c. 1665-1667). No primeiro, em uma outra versão dessa tradição especular, que em muito se aproxima do que se viu na fotografia de Cartier-Bresson, uma vista da cidade de Delft é mostrada de maneira a se fazer ver as duas margens do rio que passava por ela. Reflete, de maneira difusa, pelo movimento das águas no qual se espelha, a sombra dos edifícios à contraluz que ladeiam a margem em que se vislumbra a cidade. Interessante estratagema, necessário para criar, diferentemente do que fizeram Jan Van Eyck e Kalf, a sensação de uma cidade com profundidade no espaço. Se nas outras telas utilizou-se de pequenas zonas de sombra e claridade para dar volume aos corpos e, com isso, reconstituir a percepção da perspectiva para os olhos ávidos do observador, aqui, massas de imagem quase chapadas adquirem volume e profundidade por estarem em zonas de claro-escuro-claro, que fazem com que a vista passeie do primeiro ao último plano da pintura recuperando, por meio desse movimento, a sensação de que a cidade se espalha em direção oposta à dos nossos olhos.

Por fim, Moça com brinco de pérolas desdobra o conceito da tradição holandesa do espelho, mas, como no caso dos copos e dos vidros de janela, procurando objetos que dariam à cena um ar de naturalidade que a inserção de estranhos espelhos convexos não permitiria. Nessa tela, são três os lugares onde essa possibilidade é construída pela habilidade do pintor: os dois olhos e, evidentemente, o famoso brinco de pérolas. Se na pérola, por sua superfície mais rugosa e translúcida, já podemos vislumbrar a trama da janela por onde penetra a luz que ilumina o ambiente, são em seus olhos, brilhantes como a mais perfeita das superfícies, que se podem ver com detalhes não só a janela mas também móveis e elementos que estão no quarto, os quais não aparecem na imagem em volta da moça, pois em torno de seu dorso há apenas um fundo absolutamente escuro.

Como não remeter aqui ao filme $A$ chuva (1929), do também holandês Joris Ivens (1898-1989). O filme, que muitas vezes é comparado com os filmes da trilogia das cidades $^{11}$, realizados mais ou menos na mesma época, diferencia-se deles de maneira acentuada, pois não se trata aqui de mostrar o ciclo diário de uma cidade, da manhã à noite, ainda que mesmo nos filmes da trilogia a forma como realizam isso seja completamente diversa. Ivens não acompanha o ciclo manhã-tarde-noite de uma cidade, com seus respectivos amanhecer, trabalho, almoço, trabalho, lazer e, por fim, descanso. O que Ivens constrói é, em outra direção, o ciclo de uma chuva, desde seus primeiros indícios até o momento em que termina e quando a cidade começa a secar.

11. Rien que les heures (1926), de Alberto Cavalcanti, Berlim, Sinfonia da Metrópole (1927), de Walter Ruttmann, e Um Homem com uma Câmera (1929), de Dziga Vertov. 


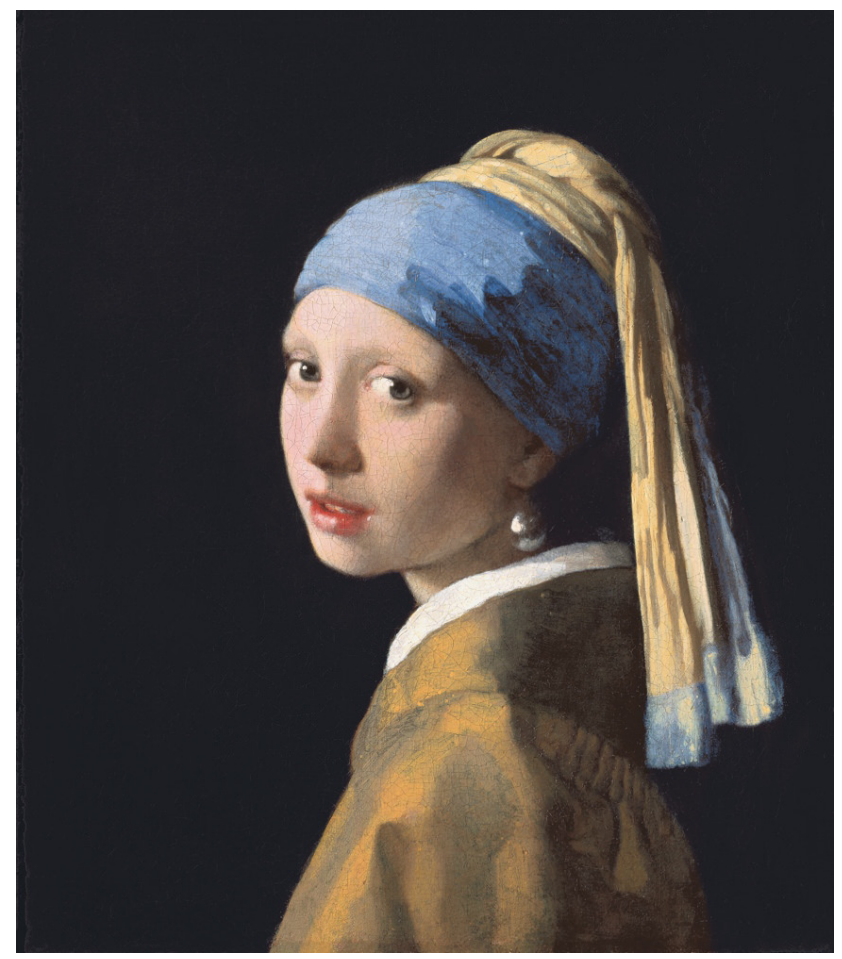

Johannes Vermeer, Moça com brinco de pérolas, Delft, c. 1665-1667.

A primeira cena mostra uma poça d'água que reflete a cidade de maneira turva, pelo seu próprio movimento, o que lembra a imagem de Vermeer em Vista de Delft. Aos poucos, a imagem da água começa a ser cortada pelas quilhas dos barcos e pelo movimento das ondas em direção às margens do rio, o que permite pensar que se trata de canais de uma cidade ${ }^{12}$. Com uma tomada de um céu escuro e cheio de nuvens carregadas, anuncia-se a chegada da chuva, o que, logo a seguir, é revelado por meio das gotas que começam a cair e, ao mesmo tempo, a turvar as imagens refletidas de uma ponte que se pode ver por seu reflexo nas águas calmas do canal.

Daí para frente, o filme adota uma perspectiva especial, um ponto de vista que na verdade não é de ninguém nem de coisa alguma. Adota-se, sugestivamente, o ponto de vista negativo de quem está na chuva, ponto de vista que vai desdobrar, como na foto de Bresson e nos espelhos holandeses, aquilo que os olhos não veem quando as pessoas se movem no mundo. Lembrando Simmel (1967, p. 19), é como se a atenção, entre os infindáveis estímulos que incitam a vida metropolitana, escolhesse seguir e organizar apenas aqueles que escapam da vida prática, do andar e se deslocar na chuva,

12. A cidade é Amsterdã, mas ela nunca é nomeada no filme, pois isso não é importante nem central no tema. 


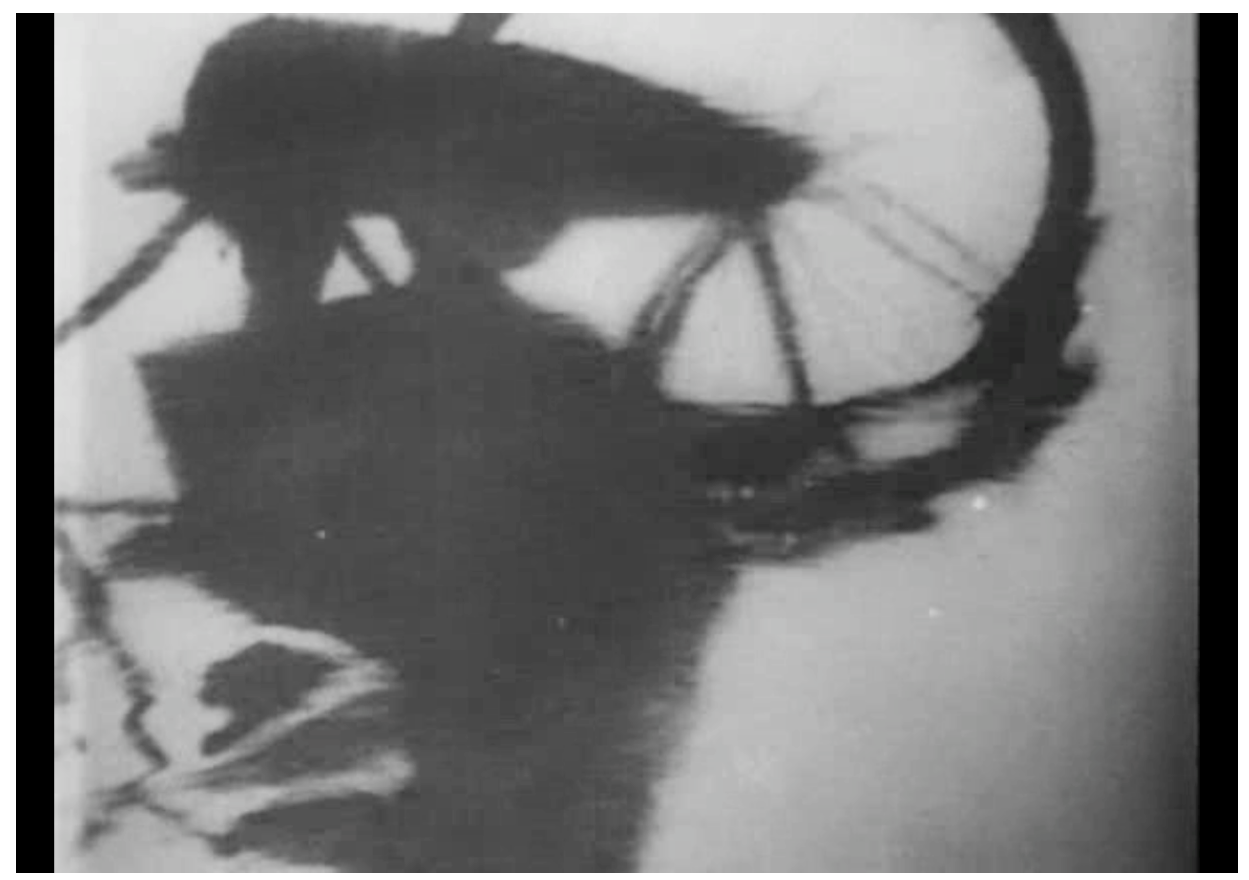

Joris Ivens, Fotograma do filme A chuva, Amsterdã, 1929.

tudo aquilo que o olho ignora para poder dar andamento a esses atos de locomoção. No filme, aparece tudo o que não se olha quando está chovendo: as gotas de água que escorrem pelos corrimãos de ferro das pontes; o chão molhado que começa a refletir, como antes faziam as águas, o que passa sobre ele, seja os passos de um transeunte, seja o movimento de um carro, seja a versão invertida ou aérea de um aglomerado de guarda-chuvas, o que permite visualizar um inusitado padrão geométrico de organização espacial, como aqueles que se podem ver em inúmeras fotos de Moholo-Nagy. Uma pequena cena, de apenas nove segundos, mostra um desses reflexos e se tornou o fotograma mais reproduzido da filmografia de Joris Ivens - virou história. É uma cena singular, que começa com uma tomada de cima de um pedaço de um guidão de bicicleta. Em seguida, a câmera se desloca e começa a seguir o trajeto da bicicleta pelo seu reflexo no calçamento, em uma imagem quase perfeita de um mundo invertido que não se dá aos olhos, assim como se viu na imagem especular do homem que salta a poça bem como nas evoluções da bailarina na foto de Bresson. A isso se somam outras imagens sugestivas em sua cotidianidade espectral: a cidade vista através de um vidro embaçado e cheio de gotículas de chuva (talvez a mais comum), mas com o foco no vidro e não na cidade, como em geral fariam os olhos, as mais variadas possibilidades de águas que escorrem, nas quinas dos beirais, nos vidros inclinados dos sótãos-moradia incrustados nos telhados da cidade, onde se pode ver a água da chuva escorrer em profusão, como nas cenas dos filmes de ficção, que para criar a 
sensação de chuva intensa, vertem sobre os vidros uma quantidade tão grande de água que, se assim acontecesse, estaríamos perto de um cataclismo climático ${ }^{13}$. $\mathrm{O}$ filme acaba com o término da chuva, o céu clareando, os reflexos no chão acalmando e aos poucos sumindo, as águas dos canais readquirindo um ar tranquilo e refletivo, seu tema central, sua alusão principal, sua sugestão intelectual.

Nesse sentido, o que o filme de Ivens mostra é um abrir de olhos em direção ao desconhecido, que está no seio do que sempre se vê e nunca se olha. É um convite para espreitar o inusitado universo de formas que permeia um mundo que sistematicamente deixa-se de lado quando interagimos com ele. É a inversão das referências organizadoras do olhar e do estar no mundo rumo a uma nova possibilidade de construção de significados, não pelo caminho do espetacular e do inaudito, mas pelas sendas do corriqueiro e do eternamente esquecido ou sublimado pelo olhar cotidiano.

A “natureza que fala à câmera não é a mesma que fala ao olhar; é outra, especialmente porque substitui a um espaço trabalhado conscientemente pelo homem, um espaço que ele percorre inconscientemente" (Benjamin, 1986, p. 94), passagem que remete àquilo que Benjamin chamou de inconsciente ótico, que só a fotografia (e o cinema, agrego eu) poderia revelar. O que esses trabalhos desvendam - fundados em proposições que já haviam encontrado seus caminhos pelas artes plásticas, mas entendidas como construções do pintor, e não do olhar - é que, no caso das fotografias e de filmes como este de Joris Ivens, os olhos são levados a investigar uma dimensão do real que não lhes é especialmente desconhecida, mas à qual também não prestam quase ou nenhuma atenção, apresentando-se, assim, uma nova configuração de mundo e, consequentemente, de possibilidades de constituição de sentidos. Ressalta-se, portanto, a capacidade que esses meios têm não de mostrar e ser um comprovante daquilo que os olhos já viram, ou da existência e efetividade de algo, como prova ou comprovação, como acredita o senso-comum e a maioria dos observadores ${ }^{14}$ - iludidos justamente por aquele atributo psicológico de objetividade discutido por Bazin, em que, justamente por ser a criação da imagem mediada por algo "mecânico" isto acabaria indiferenciando a realidade da coisa da realidade da imagem da coisa, independentemente de nossa consciência -, mas de ressaltar aos olhos uma quantidade infinita de configurações de fenômenos que sem a sua mediação passariam despercebidos ao olhar e ao intelecto.

As fotos de Diane Arbus, por sua vez, sugerem outras ilações. A princípio, seu ponto de partida é radicalmente diferente do de Cartier-Bresson. Nada de gente famosa, de

13. Sobre esses truques que o cinema utiliza para iludir a percepção, ver Carrière (1995, especialmente ao capítulo 3, pp. 103-143).

14. Incluindo-se aqui as interpretações oriundas da tradição positivista das ciências sociais em sua obsessão pelos dados e pelos "fatos". 
cenas diferentes, nada de momentos excepcionais. Pelo contrário, suas fotos parecem perdidas na continuidade pesada do dia a dia. "Eu sinto muito pouca atração em fotografar pessoas que são conhecidas ou mesmo assuntos que são conhecidos. Eles me fascinam quando eu quase não ouvi falar deles e, no minuto em que se tornam públicos, eu me torno terrivelmente inerte em relação a eles" (Arbus, 1972, p. 3).

Poder-se-ia esperar de uma frase como essa que as fotos de Diane Arbus mostrassem ações e pessoas corriqueiras perdidas na inacessibilidade de seu cotidiano. Mas, ao olhar seu trabalho, ele parece estar muito distante disso. De saída, seus assuntos, seus personagens, seus modelos em nada se aproximam do que se poderia compreender como ordinário, ao menos para a maioria das pessoas. Em uma primeira aproximação, suas fotos parecem expressar um mundo que não se dá facilmente ao olhar, sobre pessoas que não costumam circular à luz do sol, sobre assuntos que não fazem parte do lugar comum das atividades tidas como "normais". Contudo, não se trata de imagens que contemplam momentos históricos excepcionais, nem de cenas estranhas ao cotidiano.

Entre as muitas fotografias que ela realizou nos campos de nudismo dos Estados Unidos, entre 1963 e 1965, detenho-me em três. Homem aposentado e sua mulher em um campo nudista de manhã (1963) mostra uma cena absolutamente banal. Em uma sala de estar completamente corriqueira, vê-se um sofá do lado direito (que está ao lado da porta de entrada da sala aonde se chega através de uma varanda), uma poltrona do lado esquerdo, perto da janela, ao lado de uma mesinha e de uma luminária e, entre elas e o sofá, um aparelho de televisão, sobre o qual se encontram dois porta-retratos, um abajur e um relógio. Na parede, um quadro. Nada mais corriqueiro, nada mais comum e aparentemente sem interesse.

Mas, como era de se esperar em um campo de nudismo, o casal que está sentado, a mulher no sofá e o homem na cadeira, estão completamente nus. Na verdade, ambos estão calçados, ele com um tipo de mocassim e ela com uma sandália de tiras. É um casal aparentemente sexagenário, ela, ligeiramente inclinada para a frente, cruza os braços sobre as pernas deixando à mostra os seios fartos ligeiramente caídos; ele, de pernas entreabertas, deixa à mostra seu sexo. O quadro na parede mostra uma mulher, também nua, assim como estão nuas as pessoas que aparecem nas fotos. Mas, afora a estranheza que essa imagem poderia causar, o que é ressaltado é a absoluta casualidade e tranquilidade que esta cena transmite, sem demonstrar qualquer tipo de constrangimento ou de julgamento moral por parte de seus participantes, inclusive a fotógrafa. As outras duas fotos, Uma família de tarde em um campo nudista (1965) e Marido e mulher no bosque de um campo nudista (1963), possuem o mesmo ponto de partida e, no limite, o mesmo ponto de chegada. Na primeira, uma família (mãe e pai na casa dos 50 anos e filho adolescente) descansa sobre a grama ao lado de uma 


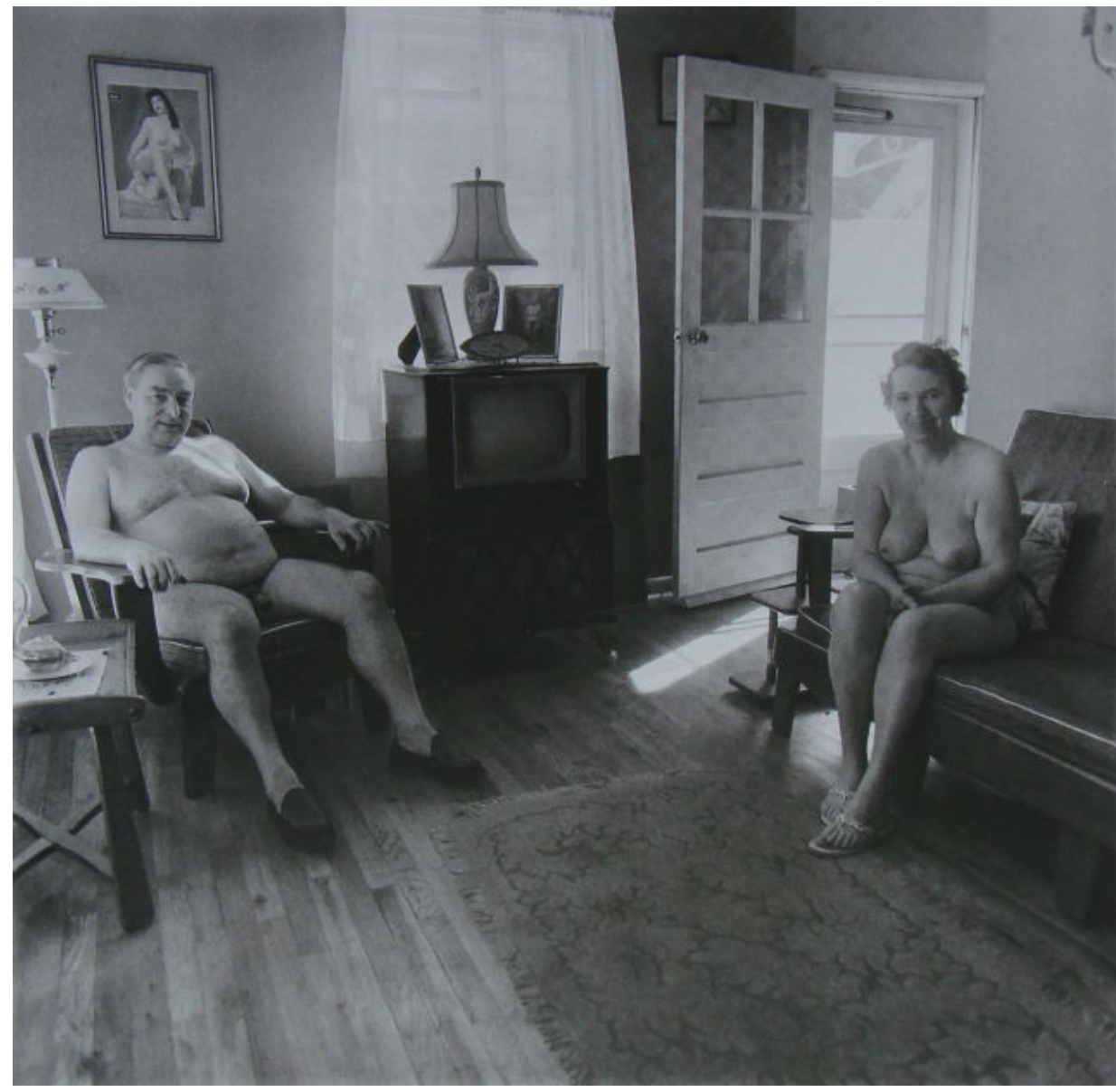

Diane Arbus, Homem aposentado e sua mulher em um campo nudista de manhã, Estados Unidos, 1963.

estrada de terra; à direita, vemos o rabo-de-peixe do carro da família estacionado. $\mathrm{Na}$ segunda, um jovem casal está de pé, entre as árvores, de mãos dadas, esboçando um sorriso para a fotógrafa. Em todas elas, as pessoas olham diretamente para a câmera, com uma naturalidade que transforma aquilo que para muitos seria inusitado na mais trivial cotidianidade, sem nenhum tipo de estranheza ou comoção.

Mas não é só disso que tratam as fotos de Diane Arbus. Veja-se, por exemplo, Rapaz com chapéu de palha esperando para entrar em uma parada pró-guerra (Nova York, 1967) e Homem jovem patriota com bandeira (Nova York, 1967).

Cada uma das fotos mostra um jovem de aproximadamente 20 anos, portando uma bandeira dos Estados Unidos em uma das mãos e estampando bottons no peito. Os dizeres estampados nos bottons do primeiro rapaz - de paletó, chapéu de palhinha e gravata borboleta - são muito significativos: "Deus abençoe a América. Apoiem nossos rapazes" e "Bombardeie Hanói”. O conjunto é assustador, pois a fisionomia 
Invisibilidades cruzadas, pp. 211-233

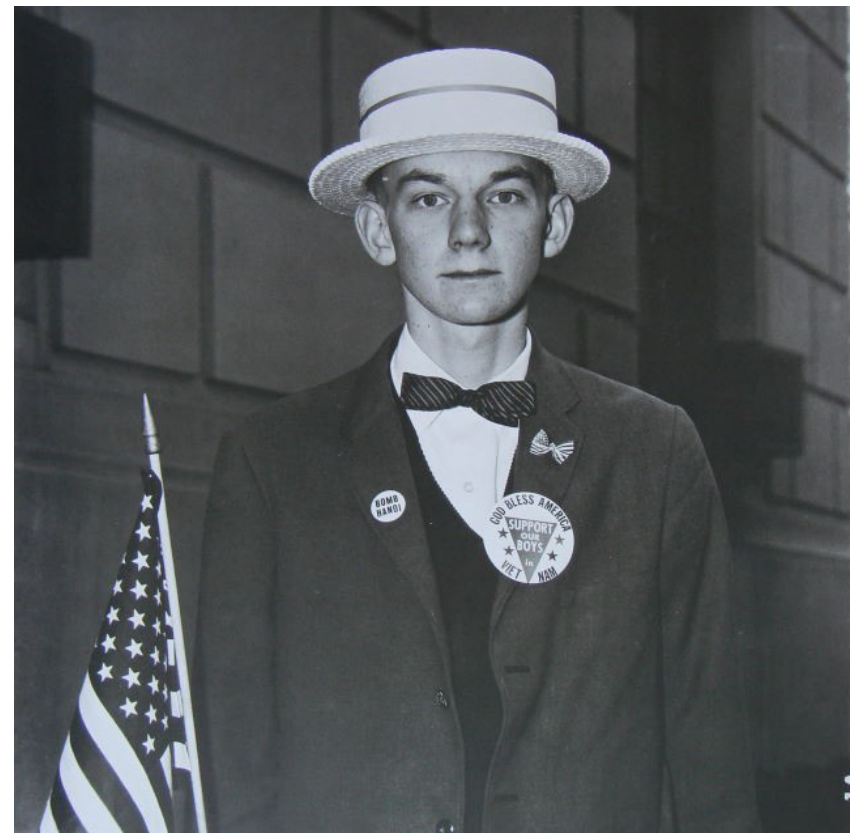

Diane Arbus, Rapaz com chapéu de palha esperando para entrar em uma parada pró-guerra, Nova York, 1967.

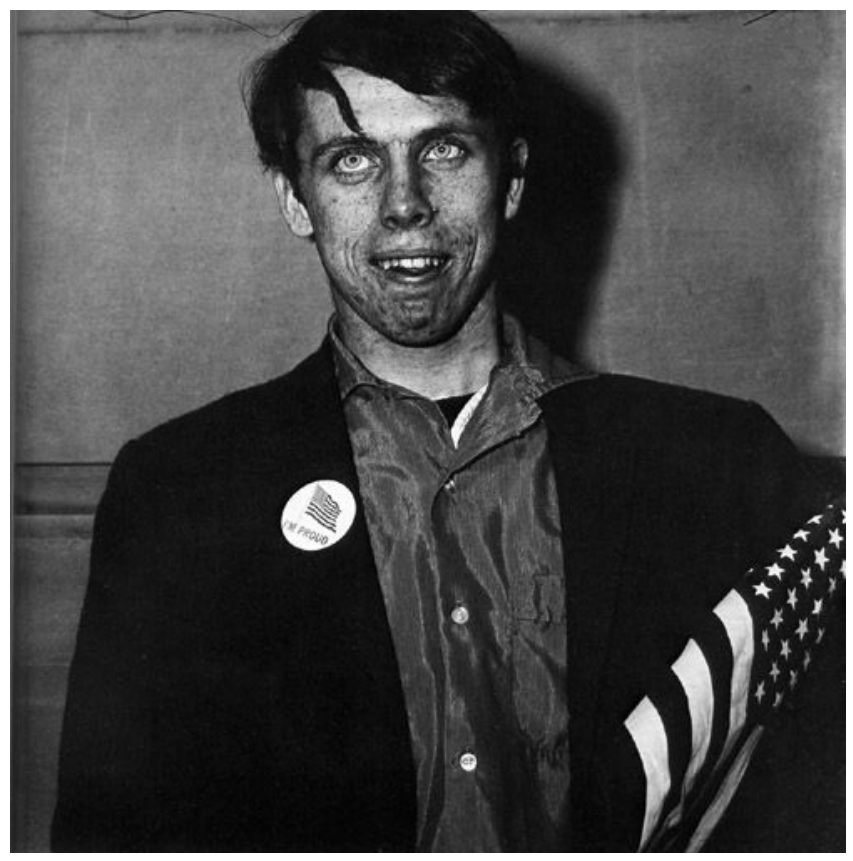

Diane Arbus, Homem jovem patriota com bandeira, Nova York, 1967 
comum e impassível do rapaz cria um enorme contraste com o que está escrito nos bottons, que instiga à matança e à guerra. Apesar das semelhanças de vestuário, o jovem da segunda foto tem um ar mais desgrenhado. Sem gravata, olhos muito claros, voltados para cima, ao contrário do outro que mira diretamente a câmera, rosto cheio de sardas, sorriso "desencontrado", no entanto está com um bottom que anuncia "Eu tenho orgulho". A similaridade entre as duas imagens está na contraposição incisiva ali estabelecida, que parece ressaltar o absurdo das propostas por eles defendidas.

Por fim, Diane Arbus realizou muitas e muitas fotos de pessoas que poderiam ser consideradas diferentes e, no limite, aberrações. Ela nunca escondeu sua atração por esse tipo de pessoas: "Freaks era uma coisa que eu fotografava bastante. Foram umas das primeiras coisas que fotografei e isso me causava um tipo forte de excitação" (Arbus, 1972, p. 3). Fotos de anões, gigantes, casais com filhos deficientes, pessoas "incomuns" como nudistas, travestis, circenses, casais interétnicos, entre outros temas. O sentido a que essas fotos aludem se explicita no ensaio sobre pessoas com síndrome de Down, realizado entre 1970 e 1971, ano de seu suicídio. Sem títulos, o que era raro acontecer, as fotos mostram pessoas se divertindo, geralmente em um campo aberto, sorrindo e brincando. A meu ver, são as fotos mais carinhosas e singelas de Arbus, pois desdobram do que poderia ser visto como o horror da doença, uma naturalidade, uma simplicidade e uma vida e alegria que poderia para muitos ser impensável nessas circunstâncias.

Esses momentos-limite dizem muito sobre as alusões que as fotos de Diane Arbus me despertam. Definitivamente, há ali uma inversão completa de valores de apreciação das coisas e do mundo. Com a amoralidade absoluta que projetamos em suas imagens, suas lentes causam uma curiosa inversão de pressupostos, pois aqueles que são tidos como estranhos, desviantes, diferentes, esquisitos, excêntricos, doentes, "anormais", aparecem em suas fotos com uma dignidade e altivez que poderiam causar estranheza em se tratando de pessoas tão fora do "comum". Ao mesmo tempo, e por outro lado, os que poderiam ser brindados pelo senso comum com a alcunha de "normais" são justamente aqueles que, pelas suas lentes, adquirem expressão tenebrosa, mais irreal, mais instigantemente desumanizada, mais... freak. E essa desnaturalização do que pode ser concebido como "estranho" é alcançada por meio de uma relação afetiva, delicada e dedicada de Arbus com as pessoas fotografadas; diferentemente do momento decisivo de Cartier-Bresson, aqui cada um constrói o seu próprio eu, como diria Goffman $(1975)^{15}$, preparando seu ambiente para nele se sentir inserido e aconchegado. É como se nessas fotos nada fosse pego de improviso. Pelo contrário, as pessoas criam seus próprios cenários para serem fotografadas, criam

15. Ver especialmente o capítulo vi, pp. 191-217. 
a própria imagem de si mesmos e, com isso, por não existirem mais bastidores a serem desvelados, por se mostrarem como se veem a si mesmos, essas fotos transmitem uma imensa e admirável sobriedade, admiração e respeito pelo outro, um outro que, muito frequentemente, não é visto dessa forma. "Muitas pessoas passam a vida com medo de passar por uma experiência traumática. Os freaks nasceram com o seu trauma. Eles já passaram o seu teste na vida. Eles são aristocratas” (Arbus, 1972, p.3).

"Eu realmente acredito que existem coisas que ninguém veria se eu não as fotografasse" (Arbus, 1972, p.15). Essa frase provoca uma nova interpretação para aquilo que apontava Benjamin e ressalta, junto com o momento decisivo de Cartier-Bresson, que a fotografia até pode aludir a coisas, mas se existe polissemia, se existe outra possibilidade interpretativa, ela está no aporte de construção de sentido do observador, que olha com os olhos de sua cultura e de seus valores, que relaciona imagens dos mais variados tipos e suportes, estimulado muito mais pelo que elas aludem que pelos pretensos "fatos" e "dados" que supostamente mostram e que uma arqueologia não interpretativa da imagem tentaria, sempre em vão, deslindar.

\section{Referências Bibliográficas}

Arbus, Diane. (1972), Diane Arbus. An Aperture Monograph. Nova York, Moma.

BAZIN, André. (1983), “Ontologia da imagem fotográfica”. In: Xavier, Ismail (org.). A experiência do cinema. São Paulo, Graal.

Benjamin, Walter. (1986), “Pequena história da fotografia”. In: Walter Benjamin: obras escolhidas. Magia e Técnica, Arte e Política. São Paulo, Brasiliense.

Berger, John. (1980), Modos de Ver. São Paulo, Martins Fontes.

CARrière, Jean-Claude. (1995), A linguagem secreta do cinema. Rio de Janeiro, Nova Fronteira.

Cartier-Bresson. Henri. (1952), The decisive moment. Nova York, Simon \& Shuster.

Chiodetto, Eder. (2009)Henri Cartier-Bresson: Fotógrafo. Catálogo da exposição realizada no Sesc Pinheiros, 7 set-20 dez. 2009.

Foucault, Michel. (1981), As palavras e as coisas. São Paulo, Martins Fontes.

FranCASTEL, Pierre. (1983), “L'objet filmique et l'objet plastique”. In: . L'image, la vision et l'imagination. Paris, Denoël/Gonthier.

Gombrich, Ernest. (1985), A História da Arte. Rio de Janeiro, Zahar.

Menezes, Paulo. (1997), A trama das imagens. São Paulo, Edusp.

Simmel, Georg. (1967), “A metrópole e a vida mental”. In: Velho, Otávio Guilherme. O fenômeno urbano. Rio de Janeiro, Zahar. 


\section{Resumo}

Invisibilidades cruzadas: uma aproximação ao conceito de o momento decisivo de Henri Cartier-Bresson.

Este artigo analisa o que se pode conceber como o conceito de o momento decisivo de Henri Cartier-Bresson, tendo em vista a proliferação de interpretações que as palavras "momento decisivo" guardam em relação ao conceito cunhado por ele. Para investigar a raiz desse conceito analisam-se algumas de suas fotos em referência a outras imagens da história da arte, como o casal Arnolfini, de Van Eyck, a natureza morta, de Willen Kalf, e as pinturas de Vermeer, além das fotografias de Diane Arbus.

Palavras-chave: Sociologia da arte; Fotografia; Henri Cartier-Bresson; O momento decisivo; Interpretação de imagens.

\section{Abstract}

Crossed invisibilities : an approach to the concept of the decisive moment of Henri Cartier-Bresson This article analyzes what can be conceived as the decisive moment by Henri Cartier-Bresson, in view of the proliferation of interpretations that the words "decisive moment" hold in relation to the concept of the decisive moment coined by him. To investigate the root of this concept, some of his photographs are analyzed in reference to other images from the history of art, such as Van Eyck's Arnolfini couple, Willen de Kalf still life and Vermeer's paintings as well as photographs by Diane Arbus.

Keywords: Sociology of Arts; Photography; Henri Cartier-Bresson; The decisive moment; Image interpretation.

Texto recebido em 5/11/2015 e aprovado em 7/6/2016. DoI: 10.11606/0103-2070.ts2017.107 156.

PAUlo MEnEzes é professor do Departamento de Sociologia da Universidade de São Paulo. E-mail:paulomen@usp.br. 